\title{
Jurgen Habermas: Problem Dialektika Ilmu Sosial
}

\author{
Santosa 'Irfaan"
}

"Penullis adalah Magister Studil Islam (M.S.I.), dosen tetap Junusan Hukum Islam (Syari"ah) STAIN Punwokerto.

Abstract. Habermas critical theory is a reconstuction effort to Frankfurt school that inspired by Karl MarXs critical theory, that facing dead end. With continuing concem of his previous thinkers to radically atter practical thinking stucture, Habermas formulate that concem with new and original critical theory concept. This is clear on changing process dimension, where Habermas choosing different way from his predecessors, with non-revolutionary and non-violence. Namely, through social transformation, with emancipate dialogs, communicative method, without domination method. Keywords: Citiical theory, Frankfurt school, Habermas.

\section{PENDAHULUAN}

Jurgen Habermas adalah tokoh terkemuka dalam sebuah aliran filsafat, yang sejak beberapa dekade* terakhir, semakin berpengaruh dalam dunia filsafat maupun ilmu-ilmu sosial, yaitu filsafat kritis. Terkadang pandangannya digunakan dalam istilah teori kritis. ${ }^{1}$ Habermas melukiskan teori kritis sebagai metodologi yang berdiri dalam ketegangan dialektis, antara filsafat dengan ilmu. Teori kritis hendak menembus realitas sosial sebagai fakta sosiologis untuk menemukan kondisi-kondisi yang bersifat transendental, yang melampaui data empris.

Dengan ekplorasi kritisnya, tampak nantinya Habermas melakukan suatu kritik ideologi dan ilmu melalui kritik pengetahuan. Pengetahuan, ilmu, dan teknologi, merupakan tiga hal yang saling berhubungan dalam praksis kehidupan manusia. Pengetahuan merupakan aktivitas, proses, kemampuan, serta bentuk kesadaran manusia, sedangkan ilmu sebagai satu pengetahuan yang direfleksikan secara metodis. Jika ilmu dan pengetahuan membeku menjadi suatu delusi atau kesadaran palsu yang merintangi praksis sosial manusia untuk merealisasikan kebaikan, kebenaran, kebahagiaan dan kebebasannya, maka keduanya telah berubah menjadi 'ideologis'. ${ }^{2}$

Teori kritis Habermas ingin membebaskan sekaligus 'menyembuhkan' masyarakat yang mendekam dalam kungkungan ideologi melalui kritik ideologi. Dalam hubungannya dengan masyarakat industri maju, seperti saat ini, teori kiritis ideologi mengemban tugas untuk membuka kedok ideologis dari positivisme, yang dalam konteks ini, tidak hanya dimaknai sebagai pandangan positivisme dalam ilmu, melainkan jauh lebih luas lagi, positivisme sebagai cara berpikir atau rasio yang menjangkit kesadaran masyarakat industri maju.

Teori kritis Habermas merupakan usaha rekonstruksi teori kritis madzhab Frankfurt yang diilhami oleh teori kritis Karl Marx, yang telah mengalami kebuntuan. Tanpa meninggalkan keprihatinan para pendahulunya untuk melakukan perubahan struktur berpikir praksis secara radikal, Habermas merumuskan keprihatinan tersebut dalam konsep teori kritis yang baru dan dapat dikatakan orisinal. Hal ini tampak dalam dimensi proses perubahan, tempat Habermas menempuh jalan yang berbeda dari pendahulunya dengan menempuh cara yang tidak revolusioner atau kekerasan. Akan tetapi, melalui jalan transformasi sosial, dengan dialog-dialog emansipatoris, dengan metode komunikasi, bukan melalui metode dominasi.

\section{RIWAYAT HIDUP DAN KARYANYA}

Jurgen Habermas dilahirkan pada tahun 1929 di Gummersbach, kota kecil dekat Dusseldorf, Jerman. Menurut Franz Magnis-Suseno, Habermas adalah anak Ketua Kamar Dagang di suatu propinsi Jerman. Kakeknya seorang pendeta. Kontras 
antara suasana keluarga yang borjuis-protestan dengan lingkungan masyarakat yang Katolik, membuat Habermas peka terhadap ketegangan-ketegangan dalam masyarakat. Di samping rumahnya ada toko buku Marxis, menjadikan Habermas banyak membaca dan menajamkan kepekaan. ${ }^{3}$ Sesudah menyelesaikan sekolah menengahnya, dia mempelajari sejarah, filsafat, dan kesusasteraan Jerman di kota Gottingen. Selain tiga bidang tersebut, dia juga sempat menekuni psikologi dan ekonomi. Hingga pada akhirnya, setelah pindah ke kota Zurich, dia mendalami kajian filsafat. Pada tahun 1954, Habermas mampu mempertahankan disertasi doktornya di Universitas Bonn, dengan judul Das Absolute und die Geschichte (Yang Absolute dan Sejarah), yang banyak dipengaruhi oleh pemikiran Heidegger. ${ }^{4}$ Sesudah merampungkan disertasinya, dia juga menekuni politik dan sering mengikuti kegiatan diskusi tentang persenjataan kembali di Jerman.

Pada tahun 1956, Habermas berkenalan dengan Institut Penelitian Sosial di Frankfurt, dan menjadi asisten Theodor W. Adorno. ${ }^{5}$ Dari Adorno, dia belajar sosiologi dan pada Institut Penelitian Sosial. Dia meneliti sikap politik para mahasiswa di Universitas Frankfurt. Hasil penelitian tersebut kemudian diterbitkan dalam buku Student and Politik. Di samping itu, kemudian dia mendalami pemikiran Marxisme. Ketekunan dalam berfilsafat, mengantarkan dia diangkat sebagai professor filsafat di Heidelberg (1961 - 1964). Namun demikian, pada tahun 1964, dia kembali ke Universitas Frankfurt karena diangkat sebagai professor sosiologi dan filsafat.

Pada awal dasawarsa 1960-an, Habermas dianggap sebagai ideolog oleh beberapa golongan, dan dia sangat populer di kalangan mahasiswa. Pada akhir tahun 1969, dia menerbitkan buku Protesbewegung und Hochschulreform (Gerakan Oposisi dan Pembaharuan Perguruan Tinggi). Buku tersebut merupakan evaluasi kritis tentang gerakan protes para mahasiswa. ${ }^{6}$ Saat masih di Frankfurt, dia juga menerbitkan buku Theorie und Praxis (1963); lantas Zur Logik der Soziahwissenschaften (Tentang Logika Ilmu-ilmu Sosial; 1967); terus Technik und Wissenschaft als Ideologie (Teknik dan Ilmu Pengetahuan sebagai Ideologi; 1968). Pada tahun 1968, pidato pengukuhan guru besarnya di Frankfurt diterbitkan dengan judul Erkenntnisund Interesse (Pengenalan dan Kepentingan Manusiawi).

Pada dasawarsa 1970-an, dinilai oleh K. Bertens, karir ilmiah Habermas selama 10 tahun di Starnberg menjadi suatu periode yang amat subur. ${ }^{7}$ Buku-buku yang terbit, Theorie der Gesselscht oder Sozialtechnologie (Teori Masyarakat atau Teknologi Sosial; 1971 ditulis bersama sosiolog Niklas Luhmann); Philosophisch-politische Profile (Profil-profil Filosofis Politis; 1971). Buku yang menunjukkan kematangan kajian filosofisnya, Legitimationsprobleme im Spatkapitalismus (Masalah Legitimasi dalam Kapitalisme Kemudian Hari; 1973). Kultur und Kritik (1973). Terus Zur Rekonstruktion des Historischen Materialismus (Demi Rekonstruksi Materialisme Historis; 1976). Adapun yang dianggap sebagai magnum opusnya dan dinyatakan sebagai puncak seluruh usaha ilmiahnya, diterbitkan pada tahun 1981, yaitu Theorie des kommumikativen Handelns (Teori tentang Praksis Komunikatif; duajilid, 1981). ${ }^{8}$

Pada dasawarsa berikutnya, buku-buku Habermas melanjutkan dan mengolah lebih lanjut pemikirannnya dalam karya besar tadi. Moralbeurusstsein und kommunikativen Handeln (Kesadaran Moral dan Praksis Komunikatif; 1983); Vorstudien und Erganzungen zur Theorie des kommumikativen Handelns (Studi Persiapan dan Tambahan pada Teori tentang Praksis Komunikatif; 1984); Der Philosophische Diskurs der Moderne (Diskursus Filosofis dari Orang Modern; 1985); Nachmetaphysisches Denken: Philosophische Aufsatze (Pemikiran Pasca-Metafisis: Esai-esai Filosofis; 1988); Erlauterungen zur Diskursethik (Penjelasan tentang Etika Diskursus; 1991); Faktizitat und Geltung: Beitrage zur Diskurstheorie des Rechts und des demokratischen Rechtsstaats (Fakta dan Norma: Kontribusi kepada Diskursus tentang Hukum dan Negara Hukum yang Demokratis; 1992); Die Einbeziehung des Anderen: Studien zur politischen Theorie (Keterlibatan Orang Lain: Studi-studi tentang Teori Politik; 1996). ${ }^{9}$

Sesudah Institut Max Planck tidak dibuka lagi, maka Habermas kembali lagi ke Universitas Frankfurt sebagai guru besar filsafat, sampai memasuki usia pensiun pada tahun 1994. Di saat itulah karir ilmiah Habermas betul-betul telah mencapai reputasi internasional yang luar biasa.

\section{BEBERAPA PEMIKIRAN JURGEN HABERMAS}




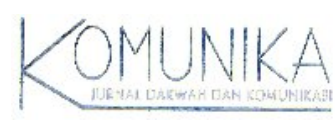

Tesis utama yang diajukan Habermas ialah menolak anggapan dasar bahwa ada pengetahuan yang betul-betul bebas dari kepentingan. Secara tidak langsung, setiap pengetahuan pasti ada suatu kepentingan yang menaungi pengetahuan tersebut. Untuk itulah, menurut Habermas, diperlukan suatu 'pencerahan' tentang kepentingan yang mendorong pengetahuan. Itulah yang membongkar selubung ideologis. Namun demikian, Habermas tidak menerima anggapan bahwa pengetahuan mesti melayani kepentingan, dalam hal ini kepentingan kelas-kelas tertentu. ${ }^{10}$

Manusia sebagai subjek dalam nalarnya, berkepentingan untuk pengetahuan. Oleh karena itu, ilmu terwujud dalam kepentingan. Dalam analisis Habermas, ada tiga macam yang didorong oleh tiga kepentingan dasar manusia; Ilmu-ilmu empiris analitis oleh kepentingan teknis, yaitu kepentingan untuk memanfaatkan apa yang diketahui. Ilmu-ilmu historishermeneutis diarahkan oleh kepentingan praktis, yaitu kepentingan untuk memahami makna. Ilmu-ilmu kritis didorong oleh kepentingan emansipatoris." Habermas menunjuk tiga kepentingan pengetahuan ini sebagai 'kuasi transendental' karena tidak bersifat empiris, melainkan masuk ke dalam struktur pengetahuan yang bersangkutan. Tiga bidang kepentingan ini paralel dengan tiga medan kehidupan manusia, yaitu alam, manusia, dan kekuasaan.

Teori kepentingan kognitif Habermas telah memberi sumbangan pemikiran yang berarti dalam mencari pertautan antara teori dan praksis dalam ilmu-ilmu sosial. Teori kepentingan kognitif Habermas telah berhasil menunjukkan kesalahpahaman dari teori positivisme logis yang merasa yakin dapat mempersatukan ilmu-ilmu di bawah satu metodologi, yaitu metodologi empiris-analitis ilmu-ilmu alam. ${ }^{22}$ Kemustahilan ambisi positivisme logis kembali ditunjukkan melalui refleksi yang bersifat transendental-pragmatis atas pengetahuan manusia. Refleksi atas ketiga macam pengetahuan itu, Habermas bermaksud mengembalikan refleksi atas ilmu pada condition of possibility masing-masing ilmu. Oleh karena itu, ilmu tidak dapat disatukan dalam satu atap metodologi sebab adanya condition of possibility yang berbeda-beda.

Syarat kemungkinan bagi pengetahuan dan tingkat praksisnya adalah kepentingan yang mengarahkan pengetahuan. Dalam hal ini, bisa diurutkan kembali tingkat pengetahuan itu. Pertama, manusia sebagai spesies mempunyai kepentingan teknis untuk mengontrol lingkungan eksternalnya melalui perantaraan kerja, dan kepentingan ini timbul di dalam pengetahuan informatif, yang secara metodis disistematisasikan menjadi ilmu-ilmu empiris-analistis. Kedua, manusia sebagai spesies memiliki kepentingan praktis untuk menjalin pemahaman timbal balik dengan perantaraan bahasa, dan kepentingan ini mewujudkan dirinya di dalam pengetahuan interpretatif yang disistematisasikan secara metodis dalam ilmu-ilmu historishermeneutis. Ketiga, kepentingan emansipatoris untuk membebaskan diri dari hambatan-hambatan ideologis, melalui perantaraan kekuasaan dan kepentingan. Kepentingan ini mewujudkan dirinya dalam pengetahuan analitis, yang disistematisasikan secara metodis, menjadi ilmu-ilmu sosial yang kritis atau kritikideologi.13

Dalam pada itu, menurut Kaelan, pemikiran Habermas - dengan mengacu pada kajian ilmu yang pernah ditekuninyaternyata tidak hanya dalam bidang filsafat saja, terutama hermeneutika dan bahasa, namun meliputi beberapa bidang ilmu, terutama ilmu sosial, kebudayaan, dan politik. ${ }^{4}$ Jasa Habermas dalam filsafat sosial adalah perjuangannya yang tidak mengenal lelah untuk menggali potensi komunikasi manusia. Meskipun sudah senja, dia tidak pernah putus asa untuk terus mencangkuli lahan komunikasi tersebut. Bahkan, Hans-Georg Gadamer pernah menjuluki Habermas sebagai master komunikasi. Boleh dikatakan komunikasi adalah tema hidup Habermas dan menjadi benang merah karya-karyanya. ${ }^{15}$

Jika dilihat kronologi kehidupan Jurgen Habermas, maka menurut K. Bertens, bisa dibagi menjadi tiga tahapan, yakni dasawarsa 1960 - 1970. Pada tahun-tahun ini, Habermas berkecimpung dengan masalah teori ilmu pengetahuan dan masih mencari-cari dalam memecahkan masalah yang dihadapi. Kemudian dari tahun 1970 - 1981, dia memilih pendekatan lain untuk mempelajari praksis komunikatif atau realitas sosial. Dalam hal ini, unsur filsafat bahasa Anglosakson dan sedikit demi sedikit menyiapkan batu bangunan untuk analisis kritisnya tentang masyarakat. Sesudah tahun 1981, dia melontarkan pemikirannya yang matang dan menyeluruh tentang realitas kemasyarakatan yang dimengerti sebagai praksis komunikatif. ${ }^{16}$

Pada buku Pengenalan dan Kepentingan Mamusiawi, Habermas menerangkan bahwa manusia memperoleh pengetahuan baru berdasarkan tuntunan kepentingan tertentu. Dalam hal ini, ada tiga kepentingan; kepentingan pengenalan teknis, kepentingan pengenalan praksis, dan kepentingan pengenalan emansipatoris. Pengenalan yang diperoleh berdasarkan kepentingan pengenalan teknis, dipakai untuk memecahkan masalah teknis, tetapi tidak berguna untuk melestarikan proses 


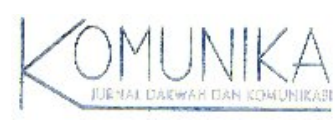

komunikatif. Adapun pengenalan yang didapat berdasarkan kepentingan pengenalan praksis, tidak dapat dipakai untuk memecahkan masalah-masalah teknis. Hanya saja cocok untuk tujuan komunikatif, guna melestarikan tradisi dan memperdalam pengertian suatu kebudayaan. Pengenalan emansipatoris hanya dapat dijalankan dalam bentuk proses yang bertujuan meningkatkan kesadaran emansipatoris. Namun, dalam periode ini, Habermas dinilai oleh K. Bertens, belum berhasil melaksanakan usaha ini dengan meyakinkan. ${ }^{17}$

Pada periode kedua, Habermas mengembangkan pemikiran penting yang menjadi unsur hakiki dalam menciptakan sintesis dari karya utamanya tahun 1981. Ada tiga unsur, yaitu teori perbuatan tutur yang dijadikan dasar untuk segala usaha teoretisnya, mengembangkan teori argumentasi dengan menciptakan pandangan luas tentang rasionalitas, dan menyediakan teori evolusi sosial sebagai pegangan untuk kemajuan kemasyarakatan.18

Teori perbuatan tutur, oleh Habermas digunakan untuk menganalisis sifat khusus dari praksis komunikatif. Inti pemikirannya bahwa berbahasa atau berbicara harus dimengerti sebagai sedang melakukan perbuatan tertentu, yaitu perbuatan tutur. Perbuatan tutur itu terdiri atas dua bagian, yakni bagian proposisional yang menunjuk kepada fakta atau kenyataan tertentu dan bagian performatif, tempat penutur menjelaskan bagaimana kenyataan itu harus dipahami oleh pendengar. Dalam hal penutur menyampaikan sifat komunikatif kepada pendengar, maka harus terkandung klaim kesahihan (validity claim), yang terdiri atas klaim kebenaran (truth), ketepatan normatif (normative rightness), dan keikhlasan (truthfulness).19

Klaim kebenaran harus diterima, jika penutur menunjukkan kenyataan dari perbuatan tuturnya sungguh-sungguh ada. Klaim ketepatan digunakan oleh penutur yang memiliki kewenangan dan hak normatif untuk melarang, bertanya, berjanji, dan lain sebagainya, sesuai dengan hak dan kewenangannya. Dengan klaim atas keikhlasan, maka penutur wajib memaksudkan atas apa yang dikatakannya, bukan sandiwara. ${ }^{20}$

Bagi Habermas, klaim kesahihan ini pada prinsipnya bisa dikritik. Pendengar dapat menolak klaim kebenaran, ketepatan, dan keikhlasan penutur dan mengajukan klaimnya sendiri yang berbeda. Kedua belah pihak harus menguji klaimklaim keshahihan secara kritis, mengemukakan pandangannya dan ditunjang alasan yang tepat. Dengan demikian, pada praksis komunikatif ditandai oleh struktur rasional internal. Ada persetujuan, tidak ada pemaksaan dan penerimaan suka rela, karena klaim kesahihan selalu mungkin dikritik. Persetujuan tersebut bertumpu pada keyakinan rasional. ${ }^{21}$

Menurut Habermas, benar adalah ucapan-ucapan yang diterima berdasarkan konsensus di antara semua pihak yang bersangkutan. Konsensus dapat dinilai rasional. Semua peserta diskusi mengemukakan argumentasi relevan yang bertumpu pada argumentasi yang terbaik. Argumentasi terbaik itu akan muncul, jika syarat komunikatif itu juga terpenuhi hingga membuahkan situasi percakapan yang ideal (the ideal speech situation), jika; (1) peserta memiliki peluang yang sama untuk memulai diskusi atau mengemukakan dan mengritik argumentasi peserta lain, (2) tidak ada perbedaan kekuasaan dalam mengajukan argumentasi, dan (3) peserta dengan ikhlas mengungkapkan pemikirannya hingga tidak ada manipulasi."2

Menurut Habermas, dalam struktur komunikasi melalui bahasa itu terkandung pencapaian hubungan bebas kekuasaan dan simetris. Artinya, kedua belah pihak, penutur dan pendengar, selalu sederajat karena komunikasi melalui bahasa ini tertuju pada persetujuan suka rela, tidak manipulatif, dan tidak dipaksakan, sebagai kunci bagi klaim kesahihan.23

Dalam pandangan Franz Magnis-Suseno, kritik terhadap Marcuse menolong Habermas membedakan rasionalitas sasaran dan rasionalitas komunikatif. Rasionalitas sasaran adalah rasionalitas tindakan instrumental, tindakan yang akan mencapai sebuah sasaran, melalui tindakan strategis. Rasionalitas sasaran itu mendasari antara dua subjek setingkat yang akan tercapai bila mereka saling mengerti. Sementara itu, rasionalitas komunikatif hanya mungkin dalam hubungan bebas sederajat antara dua subjek. ${ }^{24}$

Menurut Habermas, rasionalitas komunikatif lebih mendasar daripada rasionalitas sasaran. Dia menunjuk bahasa sebagai tempat pengalaman rasionalitas. Hubungan antara rasionalitas dan bahasa membuahkan empat klaim, yaitu pembicaraan itu harus jelas (tepat apa yang dimaksud), benar (apa yang diungkapkan), jujur (tidak bohong), dan betul (yang dikatakan itu wajar). ${ }^{25}$ 


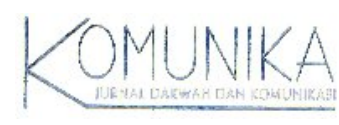

Menurut F. Budi Hardiman, sampai 1980-an, Habermas menampilkan diri sebagai teoritikus sosial daripada filosof politik. Dengan terbitnya buku Faktizitaet und Geltung (Fakta dan Keshahihan) (1992), Habermas tampil beda dengan tahun 1960 - 1980-an. Dia tidak lagi kritikus kapitalisme dan teknologi modern, seolah dia kehilangan sayap kirinya dan berubah jadi pragmatis liberal. ${ }^{26}$

Kunci untuk memahami pemikiran Habermas, adalah pembedaan antara dunia kehidupan dan sistem..7 Dunia kehidupan adalah cakrawala kepercayaan-kepercayaan latar belakang intersubjektif di dalamnya setiap proses komunikasi selalu sudah tertanam. Tiap orang berkomunikasi dan bertindak dalam dunia kehidupan. Artinya, dia hidup dalam sebuah alam bermakna yang dimiliki bersama komunitasnya, yang terdiri atas pandangan dunia, keyakinan moral dan nilai bersama. Namun, masyarakat juga tidak hanya komunitas, tetapi juga sistem. Sistem ini adalah institusi dan peraturan yang menata kehidupan masyarakat untuk meringankan beban komunikasi. ${ }^{28}$

Dunia kehidupan harus semakin menjadi rasional agar masyarakat menerima sistem yang tambah kompleks. Rasionalisasi dunia kehidupan karena semakin banyak bidang, tidak lagi dihayati atau ditata oleh adat, tetapi oleh kriteria yang dapat dipertanggungjawabkan dalam sebuah diskursus. Kata Habermas, tiap perubahan sosial membawa rasionalisasi dunia kehidupan dalam masyarakat yang bersangkutan. Artinya, acuan normatif menjadi semakin universal. Dalam hal ini, manusia perlu mensistematisasikan kehidupannya. Oleh karena itu, rasionalitas sasaran juga diperlukan. Lantas apakah normanya terlalu universal? Itu dapat dipastikan dalam diskursus yang semuanya bersangkutan terlibat. Itulah etika diskursus. ${ }^{29}$

Dalam kaitan dengan negara dan hukum dalam era globalisasi, kata Habermas, menurut F. Budi Hardiman, negara bukan satu-satunya pusat kedaulatan, melainkan hanya salah satu pusat masyarakat kompleks. Negara harus dipikirkan lain, bukan sebagai substansi kekuasaan yang mengatasi seluruh masyarakat, tetapi sebagai salah satu komponen sistemis lain yang berakar pada masyarakat dan kebudayaan dalam arti seluas-luasnya, yang disebut Lebenswelt (Dunia Kehidupan). ${ }^{30}$

Negara, pasar, dan masyarakat adalah three in one dalam memahami kehidupan sosial dewasa ini. Dalam pandangan Habermas, negara bukan satu-satunya puncak pusat masyarakat, sedangkan ekonomi dan masyarakat tunduk di bawahnya dan terhisap di dalamnya. Oleh karena pasar juga berpengaruh, tidak selalu tunduk pada regulasi negara, maka pasar bebas memiliki koneksi ke pasar global. Habermas menawarkan solusi dalam menghadapi kompleksitas ini, yaitu memahami masyarakat sebagai jaringan tindakan-tindakan sosial. Negara dan pasar adalah subsistem dari sistem sosial atas tindakan strategis dalam masyarakat luas. Sementara itu, masyarakat luas merupakan Lebenswelt, yang terdiri dari tindakan komunikatif yang merupakan elemen solidaritas sosial. Lebih dari itu, komunikasi sebagai faktor integratif masyarakat kompleks. Habermas menilai hukum sebagai sabuk pengaman terakhir bagi integritas sosial karena hukum dianggap sebagai engsel yang menghubungkan sistem dan Lebenswelt, negara dan pasar di satu pihak dan masyarakat luas di lain pihak. Artinya, hukum memberi ruang tindakan strategis, bisa dipakai sebagai alat paksa, tetapi juga harus dihasilkan dari konsensus rasional (legitim). Oleh karena itu, hukum menjembatani tindakan strategis dan komunikatif. Jika demikian, maka hukum legitim dapat membatasi ruang gerak destruktif sistem ekonomi kapitalis. ${ }^{31}$

Bagaimana menelurkan hukum legitim pada masyarakat dengan kemajemukan gaya hidup dan orientasi nilai? Habermas memberi solusi demokrasi deliberatif. Artinya, bukan jumlah kehendak perorangan dan umum yang menjadi sumber legitimasi, melainkan proses pembentukan keputusan politis yang selalu terbuka terhadap revisi deliberatif dan diskursus argumentatif. Bagaimana proseduralisme politik dan hukum dalam pengambilan keputusan itu diperoleh? Legitimasi hukum bukan pada perolehan mayoritas, tetapi cara meraihnya fair dan adil sebagai alasan kuat untuk dipatuhi oleh warga negara. Dengan kata lain, demokrasi deliberatif adalah suatu proses perolehan legitimitasi melalui diskursivitas, yang dilaksanakan secara komprehensif lewat dua rel, yaitu memperbaiki sistem demokratis dan memperkuat etos demokratis.

Filsafat politik Habermas merupakan usaha mendamaikan konsep masyarakat (gesellschaft) dan komunitas (gemeinschaft). Melalui pemahaman praksis negara hukum praksis diskursus warga negara, Habermas meninggalkan konsep individu ala liberalisme, yang dibayangkan sebagai atom dengan identitas universal yang lepas dari identitas kultural. Tiap peserta diskursus senantiasa bertolak dari konteks kulturalnya masing-masing. Akan tetapi, identitas kultural, sekali lagi, 


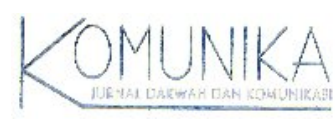

hanya titik tolak bukan ukuran. ${ }^{32}$ Dalam pada itu, multikulturalisme berarti sikap normatif tertentu untuk mengakui fakta keragaman masyarakat. Oleh karena itu, bagaimana memperlakukan keanekaragaman dalam struktur politik dan hukum yang baku? Secara garis besar ada tiga jenis rezim multikulturalisme. Pertama, rezim strategi asimilasi, yang ingin mengubah heterogenitas menjadi homogenitas. Kedua, rezim komunitarian, tempat terdapat perbedaan adat, cita-cita, dan nilai yang berbeda tak mungkin disatukan karena mereka percaya pada kemutlakan perbedaan. Ketiga, mencari keseimbangan keunikan individu dan tuntutan untuk menciptakan kebersamaan yang substantif, tidak sekadar prosedural. Di sini, ada tuntutan ganda: perbedaan sekaligus kesatuan. ${ }^{33}$ Berkaitan dengan ini, Habermas menawarkan konsep ruang publik, dia ingin menghidupkan kembali ruang publik dengan melalui proses komunikasi publik yang kritis melalui organisasi-organisasi yang menjalankan fungsi komunikasi publik itu. ${ }^{34}$

Ada teori Kompetensi Komunikatif sebagai lanjutan perkembangan pemikiran Habermas yang dinilai banyak orang lebih analitis. Pada pembahasan sebelumnya, sasaran kritik ideologi teori kritis adalah komunikasi yang terdistorsi secara sistematis. Oleh karena itu, harus diusahakan suatu perangkat teori komunikasi tersebut dengan menggunakan analisis bahasa karena berkomunikasi itu menggunakan bahasa. Melalui analisis linguistik, Habermas menyebutnya dengan teori Kompetensi Komunikatif. Teori ini merupakan sarana untuk merekonstruksi prasyarat-prasyarat umum bagi komunikasi bebas penguasaan. Dalam hal ini, dia memakai teori speech acts (tindakan tutur). Habermas menganalisis sifat khusus praksis komunikatif dengan memanfaatkan teori yang berasal dari John Austin dan John Searle. Inti teori ini bahwa berbahasa atau berbicara harus dimengerti sebagai sedang melakukan perbuatan-perbuatan tertentu. Teori ini erat sekali kaitannya dengan tindakan komunikasi sebagai salah satu matra dari praksis. ${ }^{35}$

Tujuan Kompetensi Komunikatif ini menjadikan proses komunikasi yang bebas dari penguasaan, dalam arti terdapat adanya suatu komunikasi yang genuine. Maksudnya, suatu komunikasi yang tidak terdistorsi secara ideologis, dan untuk menghasilkan komunikasi yang gemuine dan bebas distorsi ideologis ini. Menurut Habermas, kondisi masyarakat harus berada dalam situasi 'perbincangan ideal' terlebih dahulu, yang dijelaskan Habermas sebagai sebuah struktur komunikasi yang bebas hambatan dengan adanya semua partisipan dialog, kesempatan untuk memilih dan menggunakan speech acts, manakala ada suatu kesamaan kesempatan yang efektif bagi pengandaian peran-peran dialog. ${ }^{66}$ Yang dituntut dari 'situasi perbincangan ideal' adalah kebebasan partisipan berkomunikasi dalam menanggapi suatu diskursus dalam ruang publik. Mereka diberi kebebasan dan kesempatan yang sama untuk melibatkan diri dalam perbincangan dan mengemukakan, penolakan dan keterangan, serta penafsiran. Namun demikian, mereka juga dituntut harus lapang dada jika ada keputusan yang tidak menggunakan argumentasi pendapat yang mereka usulkan. Dalam komunikasi yang dialogal, untuk mencapai kebenaran yang dapat diterima, adalah pendapat yang lebih rasional dan lebih baik, bukan pendapat dari pihak yang paling berkuasa. Jadi, proses dialog mengarah pada suatu kebenaran sebagai suatu konsensus.

Dalam konteks inilah, Habermas di dalam teori kompetensi komunikatifnya menganut suatu teori the consensus theory of truth, kebenaran diperoleh lewat konsensus-konsensus rasional yang didapatkan oleh subjek-subjek yang berkompeten.7 ${ }^{37}$

Dari sini, kita dapat memahami Habermas yang berbeda dengan teori kritis pendahulunya, yang menempuh jalan revolusioner, tempat dia mengambil jalan konsensus dengan sasaran terciptanya 'demokrasi radikal', yang bertumpu pada hubungan sosial yang terjadi dalam lingkup komunikasi bebas penguasaan'. Dalam konteks komunikasi ini, perjuangan kelas dalam pandangan klasik digantikan dengan 'perbincangan rasional' yang menjadi argumentasi semangat emansipatoris.

\section{PENUTUP}

Dalam konteks dewasa ini, peran teori kritis dalam membuka kedok ideologi pengetahuan makin diperlukan. Ini mengingat tatanan dunia dan pengetahuan senantiasa dan terus didasarkan atas suatu kepentingan. Dalam hal ini, teori komunikasi Habermas sebagai paradigma yang menekankan dialog dalam memakai konsensus untuk mencari kebenaran. Kontribusi Habermas lewat teori kritisnya, bila diterapkan dalam studi Islam, sangat mungkin dan signifikan. 


\section{ENDNOTE}

${ }^{1}$ Frans Magnis Suseno, Filsafat Sebagai Ilmu Kritis(Yogyakarta: Kanisius, 1995), hal. 175.

${ }^{2}$ Fransisco Budi Hardiman, Kritk Ideologi: Pertautan Pengetahuan dan Kepentingan (Yogyakarta, Kanisius, 1993), hal. 191.

${ }^{3}$ Franz Magnis-Suseno, "75 Tahun Jurgen Habermas", dalam Basis, Nomor 11-12, Tahun Ke-53, November-Desember 2004, hal. 5.

${ }^{4}$ E. Sumaryono, Hermeneutik: Sebuah Metode Filsafat(Yogyakarta: Kanisius, 1999), hal. 87.

${ }^{5} \mathrm{~K}$. Bertens, Filsafat Barat Kontemporer. Inggris-Jerman (Jakarta: Gramedia Pustaka Utama, Cet. IV, 2002), hal. 236.

${ }^{6}$ E. Sumaryono, Hermeneutik: Sebuah, hal. 88.

${ }^{7} \mathrm{~K}$. Bertens, Filsafat Barat Kontemporer, hal. 240.

${ }^{8}$ lbid., hal. 239-240.

${ }^{9} /$ bid., hal. 241.

${ }^{10}$ Frans Magnis-Suseno, "75 Tahun Jurgen Habermas", hal. 6.

${ }^{11}$ Ibid. Lihat dan bandingkan dengan Fransisco Budi Hardiman, Menuju Masyarakat Komunikatif: Ilmu, Masyarakat, Politik, dan Postmodemisme Menurut Jurgen Habermas (Yogyakarta, Kanisius, 1996), hal. 6. Juga dalam buku lainnya, Kritik Ideologi:, hal. 131, 145 dan 163. Bandingkan pula dengan Frans Magnis-Suseno, 'Kata Pengantar' dalam buku Jurgen Habermas, Ilmu dan Teknologi Sebagai Ideologi, Terj. Hasan Basari (Jakarta, LP3ES, 1990), hal. xix - xx.

${ }^{12}$ Jurgen Habermas, Knowledge and Human Interest (Boston: Beacon Press, 1971), hal. vii. Lihat dan bandingkan dengan E. Sumaryono, Hermeneutik: Sebuah.

${ }^{13}$ Ibid., hal. 313, dan lihat juga Fransisco Budi Hardiman, Kritik Ideologi, hal. 192.

${ }^{14}$ Kaelan, Filsafat Bahasa: Masalah dan Perkembangannya (Yogyakarta: Paradigma, Cet. III, 2002), hal. 219.

${ }^{15}$ Sindhunata, "Berfilsafat di Tengah Zaman Merebak Teror", dalam Basis, Nomor 11-12, Tahun Ke-53, November-Desember 2004, hal. 48 - 50.

${ }^{16} \mathrm{~K}$. Bertens, Filsafat Barat Kontemporer, hal. 242.

${ }^{17} \mathrm{lbid}$., hal. 243-244.

${ }^{18} \mathrm{Ibid}$., hal. 244.

${ }^{19}$ Ibid., hal. 245-246.

${ }^{20} \mathrm{Ibid}$., hal. 246.

${ }^{21}$ Ibid., hal. 246-247.

${ }^{2}$ Ibid., hal. 247 - 248. Bandingkan dengan Sindhunata, "Berfilsafat di di Tengah Zaman", hal. 51, yang menyatakan bahwa unsur dasariah yang mesti ada agar perilaku yang komunikatif benar-benar bisa efektif. Pertama, dalam mengungkapkan sesuatu, orang harus benar-benar mengemukakan kebenaran. Kedua, dalam mengemukakan kebenaran itu, orang harus mengupayakan keadilan satu terhadap yang lain. Ketiga, orang harus benarbenar tulus dan bersungguh-sungguh menjalin relasi satu dengan yang lain.

${ }^{23}$ Ibid., hal. 248.

${ }^{24}$ Franz Magnis-Suseno, "75 Tahun Jurgen Habermas", hal. 6.

${ }^{25}$ Ibid., hal. 7.

${ }^{26}$ F. Budi Hardiman, "Menyimak Filsafat Politik Habermas: Demokrasi Deliberatif: Model untuk Indonesia Pasca-Soeharto", dalam Basis, Nomor 1112, Tahun Ke-53, November - Desember 2004, hal. 16.

${ }^{2}$ "Franz Magnis-Suseno, "75 Tahun Jurgen Habermas", hal. 8 dan bandingkan K. Bertens, Filsafat Barat Kontemporer, hal. 249.

${ }^{28}$ Franz Magnis-Suseno, "75 Tahun Jurgen Habermas", hal. 9.

${ }^{2}$ Ibid., hal. 11.

${ }^{30}$ F. Budi Hardiman, Menyimak Filsafat Politik Habermas, hal. 17.

${ }^{31}$ lbid., hal. $17-18$.

2llbid., hal. 21.

${ }^{33}$ B. Hari Juliawan, "Ruang Publik Habermas: Solidaritas Tanpa Intimitas”, Basis, Nomor 11-12, Tahun Ke-53, November - Desember 2004, hal. 3536.

${ }^{34}$ lbid., hal. 33.

${ }^{35}$ Fransisco Budi Hardiman, Kritik Ideologi, hal. 201. dan K. Bertens, Filsafat Barat Kontemporer, hal. 245.

${ }^{3} /$ lbid.

${ }^{37}$ lbid.

\section{DAFTAR PUSTAKA}


Bertens, K. 2002. Filsafat Barat Kontemporer. Inggris-Jeman. Jakarta: Gramedia Pustaka Utama.

Hardiman, Fransisco Budi. 1993. Kritik Ideologi: Pertautan Pengetahuan dan Kepentingan. Yogyakarta: Kanisius.

. 1996. Menuju Masyarakat Komunikatif: Ilmu, Masyarakat, Politik dan Postmodemisme Menurut Jurgen Habermas. Yogyakarta: Kanusius.

. 2004. "Menyimak Filsafat Politik Habermas: Demokrasi Deliberatif: Model untuk Indonesia Pasca-Soeharto", dalam Basis, Nomor 11 - 12 ,

Tahun Ke-53, November-Desember 2004.

Juliawan, B. Hari. 2004. "Ruang Publik Habemas: Solidaritas Tanpa Intimitas", dalam Basis, Nomor 11-12, Tahun Ke-53, November-

Desember 2004.

Kaelan, Filsafat. 2002. Bahasa: Masalah dan Perkembangannya. Yogyakarta: Paradigma.

Magnis-Suseno, Frans. 1990. "Kata Pengantar dalam buku Jurgen Habermas", dalam Ilmu dan Teknologi Sebagai Ideologi, Terj. Hasan

Basari. Jakarta: LP3ES.

. 1995. Filsafat Sebagai Ilmu Kritis. Yogyakarta: Kanisius.

. 2004. "75 Tahun Jurgen Habemas”, dalam Basis, Nomor 11 - 12, Tahun Ke-53, November - Desember 2004.

Sindhunata. 2004. "Berfilsafat di Tengah Zaman Merebak Teror", dalam Basis, Nomor 11-12, Tahun Ke-53, November-Desember 2004.

Sumaryono, E. 1999. Hemeneutik: Sebuah Metode Filsafat. Yogyakarta: Kanisius. 